\title{
Ageing - From pathophysiology to therapeutics. A review
}

\section{Envelhecimento - dos processos fisiopatológicos à terapêutica. Revisão}

\section{Ana Catarina Parreirão, Luís Monteiro Rodrigues,}

CBIOS - Experimental Dermatology Unit, Fac. Ciências e Tecnologias da Saúde, Universidade Lusófona, Lisbon, Portugal \& Lab. of Experimental Physiology, Fac. Farmácia Universidade de Lisboa, Lisbon, Portugal Universidade Lusófona, Campo Grande 376, 1649024 Lisboa, PORTUGAL

E-mail; catarina_parreirao@hotmail,com

\begin{abstract}
The human ageing process has been studied in multiple perspectives, and the scientific advances prolonging life expectancy resulted as quiteremarkable.

Over the years, changes occur in human body, and we become more susceptible to develop diseases, eventually anticipating death. The world population is getting old and the co-morbidities are increasing in the elderly, limiting their quality of life.

Several theories were developed to explain why we grow old, such as the free radicals and the neuro-endocrine theories. The main consequence of the ageing process seems to be the homeostasis modifications, resulting from neuro-endocrine disregulation, impacting all human body systems.

This review intends to resume the most recent concepts and finding on ageing pathophysiology, including pharmacokinetic and pharmacodynamical changes, that justify a special care when dealing with the elderly therapeutics.
\end{abstract}

Keywords: Ageing, Pathophysiology, Elderly, Therapeutics.

\section{Resumo}

O processo de envelhecimento humano tem vindo a ser estudado em múl tiplas perspectivas, e os avanços científicos noprolongamento da esperança de vida têm sido notáveis.

Como passar dos anos ocorrem alteraçōes que nos tomam mais susceptiveis adoença, antecipando a morte. A população está cada vez mais envelhecida e as co-morbilidades dos idosos são muito abundantes, reduzindo a sua qualidade devida.

Diversas teorias, onde se destacam a teoria dos radicais livres e a teoria neuro-endocrina, têm vindo a ser desenvolvidas para explicar o envelhecimento nomeadamente. A principal consequência do processo de envelhecimento parece ser a alteração da homeostasia, resultante da progressiva desregulação neuro-hormonal que se reflecteem todos os sistemas corporais.

A presente revisão pretende sistematizar os conceitos mais actuais acerca da fisiopatologia do envelhecimento, incluindo ainda o impacto do processo sobre os comportamentos farmacocinéticos e farmacodinâmicos na base dos quais a farmacoterapêtica no idoso ganha especial particularidade.

Palavras-chave: Envelhecimento, Fisiopatologia, Idoso, Terapêutica. 


\section{Introduction}

Ageing is characterized by a progressive decline in the stress response, which follows homeostasis deregulation, increasing the risk of disease ${ }^{[\cdot]\}}$. It is an inter-individual process, since changes occur in different ways among individuals, but it's also a intraindividual process since changes happen at different rates in each organ. Death is the ultimate natural expression of the process. ${ }^{[1-3]}$

The world population is ageing fast, and Western Europe is where we can find the largest percentage of old people ${ }^{\mathrm{k} \mid \mathrm{T}}$ (Table 1). The human life span represents one of the biggest expressions of the scientific process, but in the other hand, it also rises some specific health issues. It is very important to know more about the mechanisms leading to ageing in order to optimize the health professionals interventions, aiming to achieve better and longer life for all ${ }^{[s]}$.

\section{Introdução}

O envelhecimento caracteriza-se pelo declínio progressivo da capacidade de resposta ao stress, consequência de uma desregulação homeostática, implicundo o uumento da probabilidade de doença ${ }^{[\mathrm{B} \cdot 3]}$. É um processo inter-individual, uma vez que ocorre de forma diferente entre individuos do mesmo género, e intra-individuăl, pois as alteraçōes diferem consoante o órgão em quéstão ${ }^{[.3 .]}$, sendo a morte a expressūo natural do processo.

A população mundial está a envelhecer a um ritmo sem precedentes, sendo a Europa Ocidental a regiâo com maior percentagem de população idosa ${ }^{[A]}$ (tabela 1). Por um lado a longevidade humana representa uma das expressōes do progresso cientifico, mas, por outro, o envelhecimento acarreta problemas específicos em termos de saúde pública, pelo que o conhecimento aprofundado dos mecanismos que conduzem às alterações características do envelhecimento es fundamental, de forma a optimizar a intervenção dos profissionais de saúde, possibilitando uma melhoria da qualidade e da esperança de vida. ${ }^{[3]}$

Table 1- Percentage of aged populations over the world in 2008, 2020, and 2040 (adapted from Ref.4)

Tabela 1 -. Percentagem de populaçāo idosa por região mundial nos anos de 2008,2020 e 2040. (adaptada da Ref.4)

\begin{tabular}{|c|c|c|c|c|}
\hline & Ano /Year & $\begin{array}{l}\text { Idade / Age } \\
>65 \text { Anos }\end{array}$ & $\begin{array}{l}\text { Clade / Agé } \\
>75 \text { Anos }\end{array}$ & $\begin{array}{l}\text { Idnde /Age } \\
>80 \text { Anos }\end{array}$ \\
\hline & \multicolumn{4}{|c|}{ África } \\
\hline \multirow{23}{*}{$\hat{\theta}$} & 2008 & 4.9 & 1.6 & 0.7 \\
\hline & 2000 & 6.7 & 22 & 1.1 \\
\hline & 2040 & 12.8 & 5.0 & 2.5 \\
\hline & \multicolumn{4}{|c|}{ Asin } \\
\hline & 2008 & 6,8 & 24 & 1.1 \\
\hline & 2020 & 9.3 & 3.3 & 1.7 \\
\hline & 2040 & 16.2 & 68 & 3.7 \\
\hline & \multicolumn{4}{|c|}{ Europa de Leste / Eastern Eurooe } \\
\hline & 2008 & 14.5 & 60 & 3.0 \\
\hline & 2000 & 17.3 & 6.9 & 4.3 \\
\hline & 2040 & 24.4 & 12.6 & 7.8 \\
\hline & \multicolumn{4}{|c|}{ Europa Ocidental / Western Europe } \\
\hline & 2008 & 17,8 & 8.5 & 4.9 \\
\hline & 2020 & 20.9 & 10.1 & 6.2 \\
\hline & 2040 & 28.1 & 15.0 & 9.3 \\
\hline & \multicolumn{4}{|c|}{ América do Norte / North America } \\
\hline & 2008 & 12.8 & 6.2 & 3.6 \\
\hline & 2020 & 16.5 & 6.9 & 4.0 \\
\hline & 2040 & 20.8 & 11.6 & 7.3 \\
\hline & \multicolumn{4}{|c|}{ Oceânia / Oceamia } \\
\hline & 2008 & 10.8 & 4.9 & 2.9 \\
\hline & 2020 & 13.7 & 5.7 & 3.3 \\
\hline & 2040 & 18.5 & 9.1 & 5.5 \\
\hline
\end{tabular}


The present review was designed under the view of health professionals, considering the main factors to attend when dealing with a geriatric patient. It is essential to know the main structural and functional ctianges occurring over the years, and to understand the related mechanisms.

\section{Ageing Theorles}

The ageing process is multifactorial, meaning that it does not result from one single cause, since several processes interact and act at different levels of functional organization ${ }^{\text {DI }}$

Evolutionary theories stand that ageing results from the natural selection force decline. When reproductive capacity is overpassed and the individual is unable to reproduce, his body loses function simple because his imain goal as a member of the human specie was accomplished. ${ }^{[\text {ㅁ] }}$

Molecular theories are based in genetics regulation, suggesting that the degeneration from gene expression

-modification. A recent study states that the life span is related to the individual's genetics, probably at one of the locus of chromosome 4 that seems to promote longevity ${ }^{\text {t3 }}$

The cellular degradation theory basically says that the cellular division ability is programmed, e.g., after a determined number of divisions, a cell grows old and dies. It is though that telomeres reduction may contribute to cell degeneration progression. After a limited number of divisions, cells becomes refractory to the mitogenic stimulation ${ }^{[x, 0 \mid}$

The free radical theory is one of the most well studied theories, regarding free oxygen radicals as the primary responsible for human ageing. Figure 1 shows how these molecules interact with the human body and respective consequences. ${ }^{17}$
O presente artigo de revisão foi concebido na perspectiva dos profissionais de saúde tendo em especial conta os principais aspectos a que devem atender quando em presença de um doente geriátrico. Para tal é essencial a compreensão das alterações estruturais e funcionais que ocorrem com o passar dos anos, assim como os mecanismos subjacentes às respectivas alternçð̄es.

\section{Teorias do Envelhecimento}

O processo de envelhecimento é multifactorial, não resultando de uma causa única, significando que vários processos interagem entre si, e actuam a vários níveis da organização funcional ${ }^{13}$.

As teorias evolucionárias defendem que o envelhecimento resulta do declínio na força de selecção natural. A partir do momento em que é ultrapassada a fase reprodutiva de um individuo, o seu organismo degrada-se, pois o seu objectivo enquanto ser vivo foi atingido ${ }^{[3]}$.

As teorias moleculares baseiam-se na regulação genética, sugerindo que a degeneração resulta de alterações na expressão dos genes. Um estudo recente defende que a duração da vida está relacionada com a genética de um individuo, tendo sido identificados genes em um dos locus do cromossoma 4 que parecem promover a longevidade ${ }^{[\mathrm{B}]}$.

A teoria da degradação celular afirma que a capacidade de divisão de uma célula é programada, isto é, após se dividir um determinado número de vezes entra em senescência celular e morre. Pensa-se que a diminuição do tamanho dos telómeros que ocorre em cada divisăo celular pode contribuir para a degeneração progressiva da célula ao longo do tempo. Após um número finito de divisões, as células tornam-se refractárias à estimulação mitogénica ${ }^{[\text {..ศ }}$.

A teoria dos radicais livres é uma das mais bem estudadas actualmente, e assenta no facto dos radicais livres de oxigénio serem os responsáveis pelo envelhecimento do organismo. A figura 1 ilustra de que forma estas moléculas exercem a sua funçĩo no organismo e quais as suas consequências ${ }^{[7]}$ 


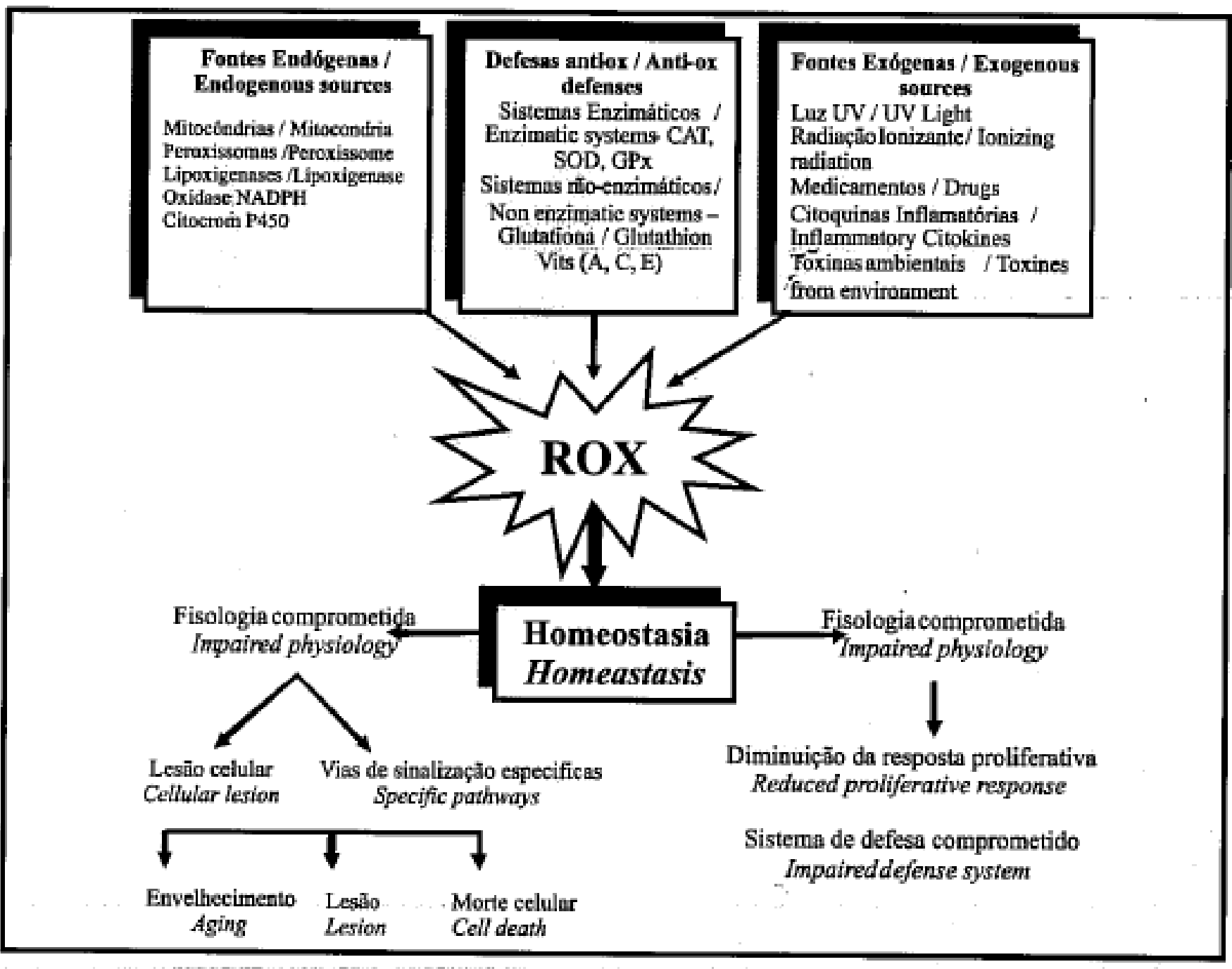

Figure 1-Oxygen Free Radicals action mechanism. Oxidative stress may result from endogenous or exogenous agents. Oxygen reactive species are unstable molecules but with long life spans. The body has different ways to neutralize these nadicals. However when the ROX production increases, the system cannot effectively eliminate them. The free form will react with lipids and DNA chinging its molecular structure, promoting lesion. Other specific signaling pathways are also activated, namely inflammatory factors which are are in the very basis of aging. (adaptado da ref.7)

ROX - free oxygen radicals and related oxidative reactions.

Figura 1 -. Mecaniș̣no de acçĩo dos radicais livres de oxigénio. O stress oxidativo pode resultar da acção de agentes endógenos ou exógenos. As eșpécies reactivas de oxigénio săo moléculas instáveis e com um tempo de vida prolongado. O organismo possui ferramentas capazes de neutralizar estes radicais. No entanto, quando a produção de ROX está aumentada, o sistema não consegue eliminá-los de forma eficaz. Na forma livre, vão reagir com proteinas, lipidos e DNA, alterando a sua estruturn molecular, e causando lesão. São também activadas vias de sinalização especifícas, nomeadarnentè factores inflamatórios, que estẫo na base do processo de envelhecimento (adaptada da ref. 7).

ROX-radicais livres de oxigénio e reaç̧öes oxidativas relacionadas

\section{Modifications of homeostatic control}

Homeostasis is defined as the ability to maintain the internal conditions in a suitable steady state, even when changes caused by external or internal factors, occur $^{[0]}$

The neuro-endocrine system is the key element in homeostatic regulation ${ }^{m}$. Ageing not only contributes

\section{Modificações do controlo homeostásico}

A homeostasia define-se como a capacidade de manutenção de condiçōes internas constantes, mesmo perante alterações induzidas por agentes externos ou internos. ${ }^{\left[{ }^{6}\right]}$

O sistema neuro-endócrino ế o elemento principal da regulação homeostasica. ${ }^{|n|}$. 
to decrease hormonal production, but also to reduce hormone receptors in target cells. ${ }^{\text {.9] }}$

The hypothalamic-pituitary axis is the main integrated regulator in human body. One of his most important functions is to verify the physiological adjustments needed to mantain internal homeostasis, regardless the environment. Throughout life, the continuous exposure to stressing factors, reduce or weaken the ability of human body to adapt and cause "adaptation diseases " and eventually, death ${ }^{(n)}$. As shown in Table 2, glands change their hormone production with ageing, contributing to the physiological changes that characterize the geriatric population. ${ }^{[m}$
O eavelhecimento contribui não só para uma diminuição da produçẩo hormonal, como também para uma redução do número de receptores hormonais nas células alvo ${ }^{\text {[n }}$

O eixo hipotalâmico-hipofisário é o principal regulador integrado do corpo bumano. Uma das suas principais funçōes é verificar os ajustes fisiológicos necessários para a prevenção da manutençüo da homeostasia intema, independentemente das alterações do meio ambiente. Ao longo da vida, a continua exposiça a agentes de stress desgastam ou enfraquecem a capacidade de adaptação do organismo e originam as "doenças de adaptaçäo" e por fim, a morte. ${ }^{\text {'] }}$. Como se pode observar pela tabela 2 , as glândulas alteram a sua produçāo hormonal com o envelhecimento, o que contribui para as alterações fisiológicas caracteristicas da população geriátrica ${ }^{[m}$.

\begin{tabular}{|c|c|c|c|}
\hline Local & $\begin{array}{l}\text { Bormons } \\
\text { Hormane }\end{array}$ & $\begin{array}{l}\text { Modificacio } \\
\text { Madificution }\end{array}$ & Impacto \\
\hline $\begin{array}{l}\text { Hipofise } \\
\text { Hypophists }\end{array}$ & $\mathrm{GH}$ & $\downarrow$ & 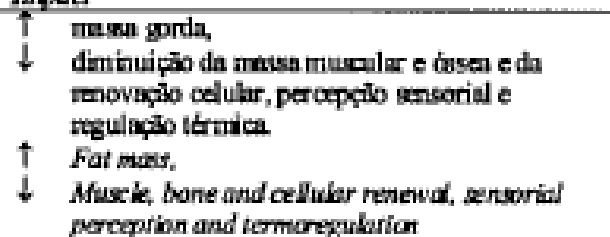 \\
\hline $\begin{array}{l}\text { Adronal } \\
\text { Mechis }\end{array}$ & $\begin{array}{l}\text { Epinefring e } \\
\text { Norepinetins } \\
\text { Epindrine and } \\
\text { Nonnepinufine }\end{array}$ & $\downarrow$ & 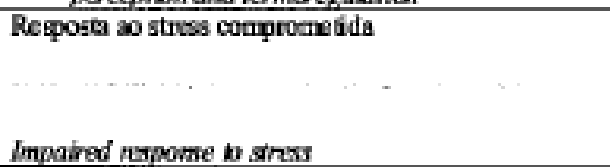 \\
\hline \multirow[t]{2}{*}{ Adrend cortex } & $\begin{array}{l}\text { Allostercia } \\
\text { Ablosternone }\end{array}$ & $\bar{D}$ & 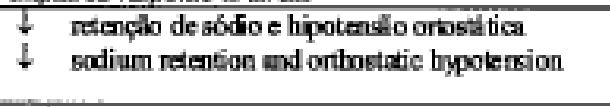 \\
\hline & Costisol & $\begin{array}{c}-\cdots+\cdots \\
\cdots\end{array}$ & 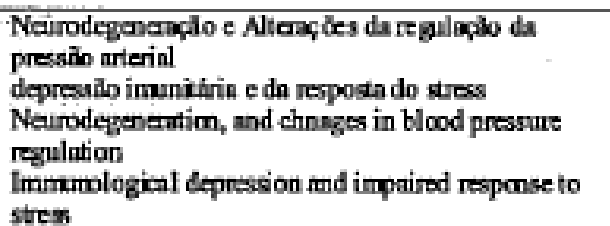 \\
\hline $\begin{array}{l}\text { Trido } \\
\text { Tyroid }\end{array}$ & $\mathrm{T} 3$ & $\downarrow$ & $\begin{array}{l}\downarrow \text { metebolisamo besal } \\
\downarrow \text { basal metibolism }\end{array}$ \\
\hline $\begin{array}{l}\text { Pantiroides } \\
\text { Pasatymoids }\end{array}$ & PTH & $\uparrow$ & $\begin{array}{l}\uparrow \text { Lbertaḉlo do cáleb do osso } \\
\uparrow \text { Bone degradation }\end{array}$ \\
\hline \multirow[t]{2}{*}{ Pancruas } & $\begin{array}{l}\text { Insulia } \\
\text { Inselin }\end{array}$ & $\begin{array}{l}\downarrow \\
\downarrow \\
\text { e sensibilidadedas } \\
\downarrow \quad \text { Receprors } \\
\text { and? oels sensitivity }\end{array}$ & $\begin{array}{l}\text { Hiperdictini - Drbetes tipo } 2 \\
\text { Hypenglicenin -type } 2 \text { Dinbetes } \\
\uparrow \text { sacidy }\end{array}$ \\
\hline & Greaga & $T$ & $\begin{array}{l}\text { Hpergicturia } \\
\text { Hypergliomia }\end{array}$ \\
\hline \multirow[t]{2}{*}{ Ovirio } & Estradiol & $\downarrow$ & $\downarrow$ litido \\
\hline & $\begin{array}{l}\text { Progesteroce } \\
\text { Progeterome }\end{array}$ & $\downarrow$ & $\begin{array}{l}\text { Instakikde vasomotora } \\
\text { Vavomobr unskbilay }\end{array}$ \\
\hline Onary & FSH & T & 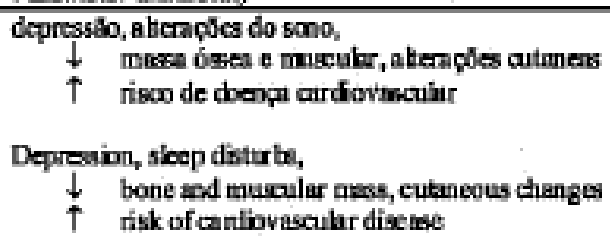 \\
\hline $\begin{array}{l}\text { Testiculo } \\
\text { Testicule }\end{array}$ & $\begin{array}{l}\text { Testosterom } \\
\text { Tertosterone }\end{array}$ & $I$ & $\downarrow \quad$ litido \\
\hline
\end{tabular}


a)

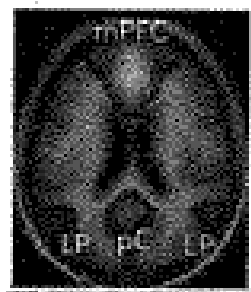

Young/Jovem

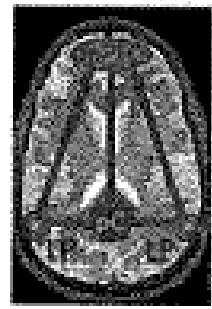

Young / Jovem

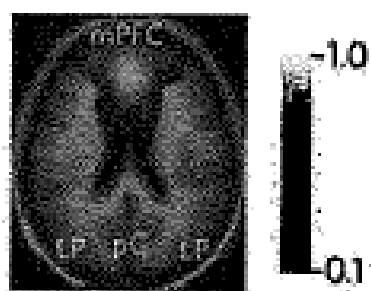

Elderly/ Idoso

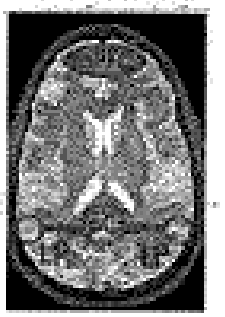

Elderly / Idoso

b)

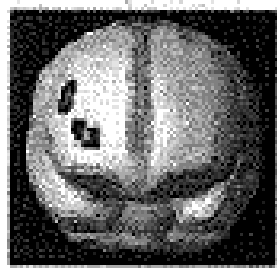

Young / Jovem

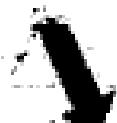

Compensatary recruitument of other regions

Recrutamento compensatúcio de zonas cerebrais

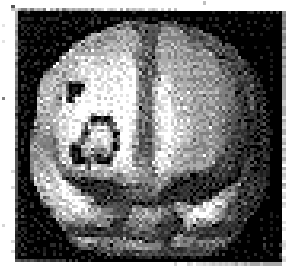

Elderly / Idoso

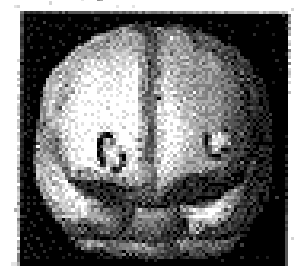

Elderly / Idoso

Figure 2 -Age related changes in brain functional systems (adapted from ref. 10) a) active nrain áreas in youngsters during a given task. There's s simultaneous activation of the pre-frontal medial cortex (mPFC), posterior cingulato (pC) and parietal lateral cortex (LP). In the eldery only the pre-frontal medial cortex was active. Eventual conexions among mPFC, pC and LP are shown in the bottom. In the old individuals, conexions are impaired meaning a lower coordinatiion capecity. b) individuals were submitted to a memory test. In the youngster, with a normal cognitive capacity,activation of the brain right lateral area was shown. In the elderly, with a reduced performance capacity, the right lateral area activation was also shown. The old individual showing to maintain the memory capacity revealed a bilateral brain activation, suggesting some recruitment of other brain areas. This would compensate for the known age related neural decline.

Figura 2. - Alteração da activação funcional dos sistemas cerebrais com o envelhecimento. (adaptada de ref.10) a) áreas cerebrais activas nos individuos jovens durante o desempenho de umn tarefa. Verifica-se uma activação simultânca do córtex pré-frontal medial (mPFC), cingulato posterior (pC) e córtex parietal lateral (LP). Nos idosos apenis a zona medial pré-frontal do córtex demonstrou estar activa. Em baixo esțo as possivítis cónexóes entre as zonâs mPFC, pC e LP. No idoso, as conexōes estảo comprometidus, o que contribui para uma diminuição da capacidade de coordenaçâo. b) os indivíduos foram submetidos a um teste de memória. No jovern, com uma capacidade cognitiva normal, foi demonstrada uma activação da zona lateral direita do cérebro. No idoso com menor capacidade de desempenho verificou-șe também uma activaç̃o da zona lateral direita cerebral. $\mathrm{O}$ idoso que demonstrou manter a capacidade de memória revelou uma activaçäo bilateral cerebral, sugerindo um recrutamento de outras zonas cerebrais de forma a compensar o declinio neuronal característico do envelhecimento

Regarding the nervous system, ncuronal death happens with the years passing by. However, as illustrated in Figure 2, the central cell loss may be compensated by an extension of the dendritic tree and increased synaptogenesis from other neurons. The regenerative capacity is provided by intercellular mechanisms such as oxidative phosphorylation and gene transcription that change with age. Thus, commitment of neuroprotective mechanisms in central nervous system evoke progressive neurodegencration, leading to dementia, delusion, and neurodegenerative disorders such as Alzheimer's and Parkinson's. ${ }^{[10, i n]}$

Nerve transmission becomes slower with age. The levels of choline acetyltransferase, acid gaminobutyric acid (GABA) and serotonin decrease, as well as the number of cholinergic receptors, even in the
Relativamente ao Sistema Nervoso, com o passar dos anos ocorre morte neuronal. No entanto, tal como está ilustrado na Figura 2, a perda celular a nivel central pode ser compensada por uma extensăo da árvore dendritica e aumento da sinaptogénese dos restantes neurónios. A capacidade regenerativa é assegurada por mecanismos intercelulares que se alteram com a idade, como por exemplo, a fosforilaçäo oxidativa e a transcrição genética. Assim, ao estarem comprometidos os mecanismos neuro-protectores do sistema nervoso central, verifica-se uma neurodegeneração prógressiva, que leva ao desenvolvimento de demência, delírio, e patologias neurodegenerativas, como as doenças de Alzheimer e de Parkinson. ${ }^{[\infty, 11]}$

A transmissão nervosa torna-se mais lenta com o 
absence of neurodegenerative disorders ${ }^{[12]}$. Cerebral blood flow decreases with age, especially in the prefrontal region of the brain. ${ }^{\left[{ }^{1 !}\right]}$ Reasoning becomes slower, and there is memory loss. These changes are not identical in all individuals, varying in the occurring extent $^{\left[{ }^{[+]}\right.}$

\section{Structural and Funetional Changes in Body Systems}

\section{Metabolism and Expended Energy}

Some studies have shown a reduction in the age related energy expenditure, as represented in Figure 3, resulting from a decrease in physical activity and basal metabolic rate. ${ }^{[2,25]}$ envelhecimento. Os niveis de colina $O$ acetiltransferase, acido g-amino-butirico (GABA) e serotonina diminuem, assim como o numero de receptores colinergicos, mesmo na ausência de patologias neurodegenerativas ${ }^{[2]}$. O fluxo sanguíneo cerebral diminui com a idade, principalmente na regiäo pré-frontal do cérebro. ${ }^{[13]} \mathrm{O}$ raciocinio torna-se mais lento e verifica-se perda de memória. Estas alterações não são idênticas em todos os individuos, variando a extensão em que ocorrem. ${ }^{\mid\left[\left.\right|^{4} \mid\right.}$

\section{Alterações Estruturais e Funcionais dos Sistemas Corporais}

\section{MetabolismoeGastoEnergético}

Alguns estudos demonstram uma redução do gasto energético com o envelhecimento, tal como se pode observar na Figura 3, resultante de uma diminuiçẵo da actividade fisica e da redução do metabolismo basal. ${ }^{\text {prs }}$

\section{CET / TEE (Mjoules/d)}

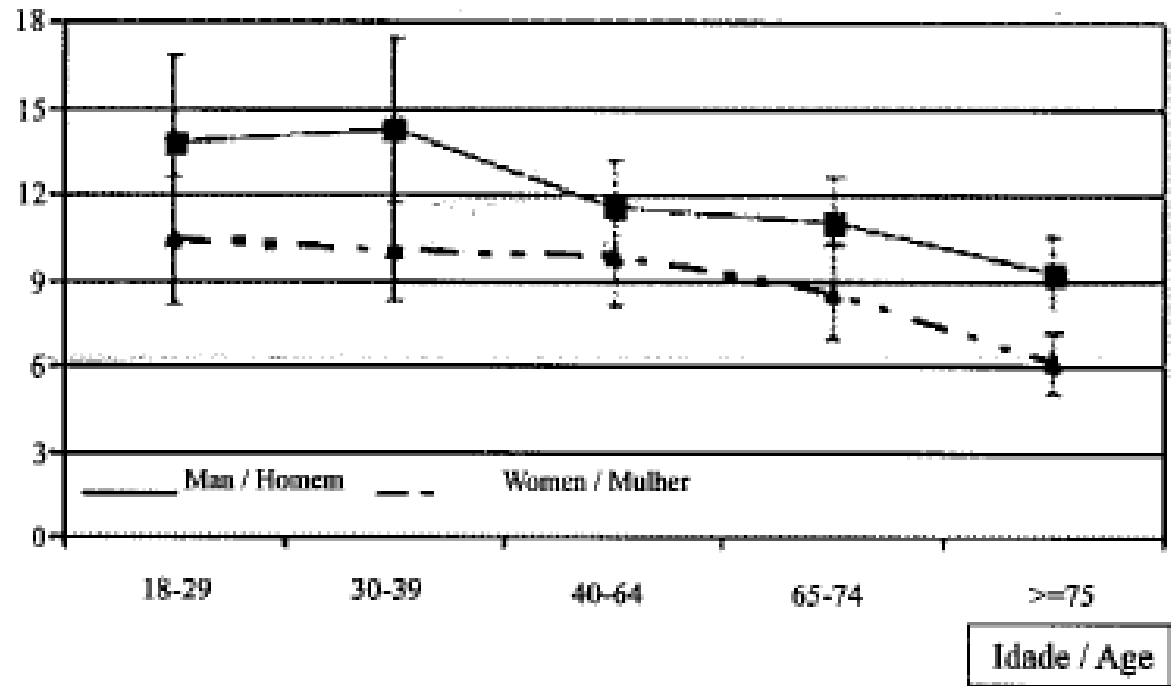

Figure 3 - Total (age related) energetic expenditure (TEE, MJoules/day) (adapted from ref. 25)

Figura 3 -, Consumo energético total (CET em MJoules / dia) relecionado com a idade (adaptado da ref.25)

The food intake is reduced with age, resulting from increased levels of serum glucose, prolonging satiety [is, 29. Often, reduction of the food intake may evoke nutritional deficits, even considering the lower levels of expended energy, further compromising the geriatric patient health condition ${ }^{[\mathrm{ita}]}$ Body temperature regulation is also modified with
A ingestão de alimentos reduz-se com o passar da idade, resultante do aumento dos niveis de glicose sérica, que prolongam a sensaçăo de saciedade. ${ }^{[3,}, 2 \mathrm{~m}$. Em geral, apesar do gasto energético estar reduzido no idoso, o menor aporte alimentar origina frequentemente carências nutricionais que podem comprometer a saúde do doente geriátrico. ${ }^{\text {[a }}$ 
ageing, specially due to a decrease in the vasoconstriction - vasodilatation response. ${ }^{\text {pn }}$

\section{Cutaneous Changes}

Skin looks clearly illustrate the physiological changes occurring with ageing over the years ${ }^{[2]}$. Tables 3 and 4 summarizes the main functional changes that causes the appearance characteristics of the elderly.

No matter the intrinsic factors conditioning the process (genetics, cellular senescence, oxidative stress, immunological competence and apoptosis, and life styles, in which the cigarette smoke plays a major role) [2. 9] other extrinsic (photo-induced) factors are specially relevant for the lower skin phototypes (accumulated UVR, oxygen free radicals generation and DNA damage, including enzymatic, metabolic and immunological alteration) ${ }^{[2, x]}$.
A regulação da temperatura corporal está igualmente comprometida com o passar dos anos, devido a uma menor capacidade devasodilataçãoevasoconstrição. ${ }^{[x \mid}$
Alterações Cuțîneas
É através da aparência cutâneä que melhor se observam as alterações fisiológicas que ocorrem ao longo dos anos [n]. As tabelas 3 e 4 resumem as principais modificaç̋̃es funcionais que estão na origem da aparência característica do individuo idoso.
Para além dos factores intrínsecos que condicionam o processo (a genética, a senescência celular, o Stress Oxidativo a competência imunitária e a apoptose, e os hábitos de vida onde o tabaco desempenha um papel principal) ${ }^{[29.19]}$ outros factos extrínsecos (Fotoinduzidos) ganham especial relevância nos fototipos mais claros (UVR acumulada, geração de radicais livres de oxigénio e danificação do DNA, incluindo a alteração de mecanismos enzimáticos, imunológicos e metabólicos ${ }^{[2.5 ?}$

Table 3 - Functional decline in the ageing skin

Tabela 3. - Funçōes em declíneo no envelhecimento da pele

- Renovação cellular

- Cell renewal

- Função "barreira"

- Barrier function

- Clearence quimica

- Chemical clearance

- Percepção sensorial

- Sensorial perception

- Proteç̧ão mecânica

- Mechanical protection

- Reparação celular

- Cellular repair
- Resposta Imunológica

- Immune response

- Termoregulação

- Thermoregulation

- Produção sebácea

- Sebaceous production

- Produção sudorípara

- Sudoriparous production

- Produção de Vit. D

- Vit D production

- Reparação do ADN

- DNA repair 
Table 4. - Skin structural and functional changes oceurring in the elderly ${ }^{\text {ias21 }}$

Tabela 4 - Alteraçōes estruturais e funcionais que ocorrem na pele dos individuos idosos ${ }^{\text {[ar } 21}$

\begin{tabular}{|c|c|c|}
\hline & $\begin{array}{l}\text { Alteração estrutural } \\
\text { Structural changes }\end{array}$ & $\begin{array}{l}\text { Consequência } \\
\text { Consequences }\end{array}$ \\
\hline $\begin{array}{l}\text { Epiderme } \\
\text { Epidermis }\end{array}$ & $\begin{array}{l}\downarrow \text { junçåo derme-epiderme, e área entre carnadas } \\
\downarrow \text { funçäo barreira e lipidos epidermicos } \\
\downarrow \text { densidade e numero dos Melanócitos } \\
\downarrow \quad \text { dermal-epidermal junction and between layers } \\
\quad \text { area } \\
\downarrow \text { barrier function and epidermal lipids } \\
\downarrow \text { melanocyte density and number }\end{array}$ & $\begin{array}{ll}\downarrow & \text { transferência de nutrientes e } \mathrm{O} 2 \\
\uparrow & \text { PTEA, pele seca e desidratada } \\
\uparrow & \mathrm{r} \text { isco carcinogénico (UV) e pele mais } \\
& \text { clara } \\
\downarrow & \text { nutrients and } \mathrm{O} 2 \text { exchange } \\
\uparrow & \text { TEWL, dry dehidrated skin } \\
\uparrow & \text { Cancer risk (UV) and lighter skin }\end{array}$ \\
\hline Derme & $\begin{array}{l}\downarrow \quad \text { Fibroblastos, fibras elásticas e desorganização } \\
\text { das fibras de colagénio } \\
\downarrow \text { microcirculação } \\
\downarrow \quad \text { Fibroblasts, elastic fibers end disorganized } \\
\text { collagen fibers } \\
\downarrow \text { microcirculation }\end{array}$ & $\begin{array}{ll}\uparrow & \text { rugas e flacidez } \\
\downarrow & \text { transferência de nutrientes e } \mathrm{O} 2 \\
\downarrow & \text { termoregulação e resposta inflamatória } \\
\uparrow & \\
\uparrow & \text { wringles and slackness } \\
\downarrow & \text { nutrients and } \mathrm{O} 2 \text { exchange } \\
\downarrow & \text { thermoregulation and inflammatory } \\
\text { response }\end{array}$ \\
\hline $\begin{array}{l}\text { Hipoderme } \\
\text { Hypodermis }\end{array}$ & $\begin{array}{l}\uparrow \text { abdomen e cintura, } \\
\downarrow \text { reduzida na face } \\
\uparrow \text { abdomen and waist } \\
\downarrow \text { reduced in the face }\end{array}$ & $\begin{array}{l}\text { Alteração do contomo corporal } \\
\downarrow \text { Resistência ao frio e ao trauma } \\
\text { Changes in body contour } \\
\downarrow \text { Resistance to cold and trauma }\end{array}$ \\
\hline Aneros & $\begin{array}{l}\downarrow \text { unidades capilares e melanócitos } \\
\text { Hipertrofia da glândula sebácea } \\
\downarrow \text { capilar units and melanocytes } \\
\text { Hypertrophic sebaceous glands }\end{array}$ & $\begin{array}{l}\text { Alopecia, cabelo grisalho, pele mais clara } \\
\text { Dermatite seborreica, pele seca } \\
\text { Alopecia, grey hair and lighter skin } \\
\text { Seborrheic Dermatitis, and dry skin }\end{array}$ \\
\hline
\end{tabular}

\section{Myo-Osteo-Articular Changes}

The myo-osteo-articular system accounts for the structural support of the human body, where muscles provide the force to ensure the movement. Thus, muscular-skeletal disorders affect posture, motion and ability to generate force ${ }^{\text {[3! }}$.

Primarily, ageing causes a decrease in bone mass with the typical osteoporosis, mostly emerging with the neuro-endocrine support modification, but also with the reduction of the physical activity (table 5). Reduction of strength and muscle mass, as well as joints degeneration and reduction of tendon stiffness, are also consistent findings ${ }^{[m]}$. Table 5 lists the main mechanisms involved in the progressive loss of myoosteo-articular function with ageing. ${ }^{\text {[2] }}$

\section{Alterações Osteo-Mio-Articulares}

O sistema osteo-mio-articular é o responsável pelo suporte e estrutura do corpo, onde os músculos fornecem a força para assegurar o movimento. Modificações na postura, na capacidade de geração de força e na rapidez de execução do movimento são consequências de alteraçōes músculo-esqueléticas. ${ }^{p !}$ Primariamente, o envelhecimento determina uma dimintuição da massa óssea, a típica osteoporose do idoso muito relacionada com a alteração do suporte neuro-endócrino bem como com a redução da actividade (tabela 5). A diminuiçăo da força e massa muscular, assim como degeneração das articulações incluindo diminuição da rigidez dos tendōes estão consistentemente presentes ${ }^{\left[{ }^{3}\right]}$. Na tabela 5 estão enumerados os principais mecanismos que originam a perda progressiva de funcionalidade osteo-mioarticular com o evoluir da idade. 
Table 5 - Summary of the most important changes occurring in the elderly's skeleton and muscle, and mechanisms involved ${ }^{[\mathrm{p}-\mathrm{m}]}$

Tabela 5 - . Resumo das principais alteraçōes do esqueleto e músculo que ocorrem no idoso e mecanismos subjacentes. ${ }^{\text {jel }}$.

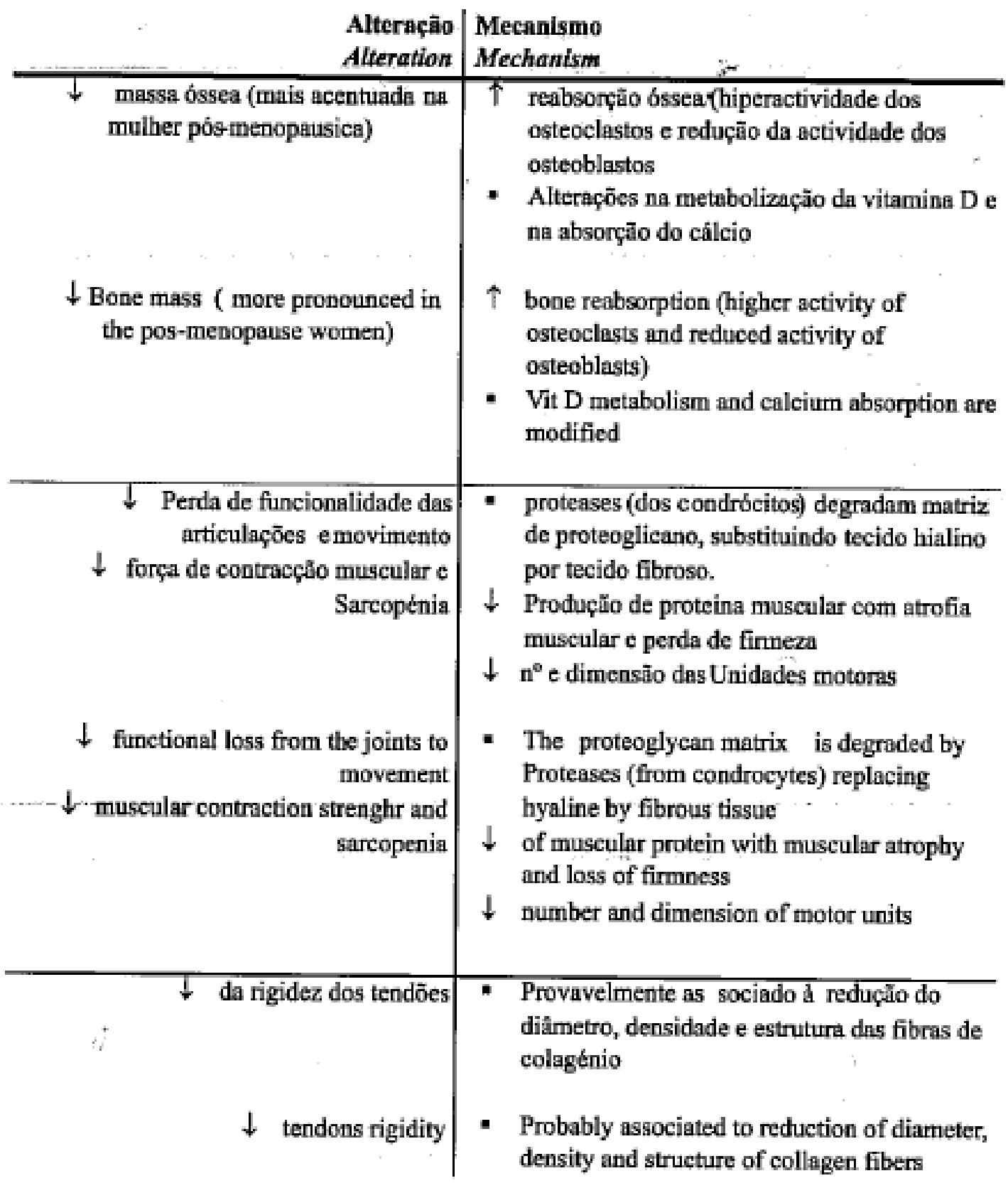

\section{Hematological and Immune Changes}

Concerning hematology, the geriatric population often shows consistent shortage of iron, B12 vitamin and folic acid, which may contribute to the increased prevalence of red strain diseases, particularly anemia ${ }^{[*]}$. The hematopoietic response in stress is irregular and a reduction in the erythropoietin secretion is seen over the years. ${ }^{|t| 1}$

Changes in hemostasis are common with ageing

\section{Alterações Hematológicas e Imunitárias}

A nivel hematológico verifica-se frequentemente na população geriátrica carências em ferro, vitamina B12 e de ácido fólico, o que pode contribuir para o aumento da prevalência de patologias na linhagem vermelha, nomeadamente, anemias. ${ }^{\mu-1 / 9}$ A resposta hematopoiética perante situaçőes de stress é irregular, verificando-se uma redução da produção de eritropoietina com o passar dos anos. ${ }^{[\text {ti] }}$ 
specially involving the increase of some clotting factors, and a faster platelet response to aggregation stimulus, increasing the risk of embolism ${ }^{\text {(e) }}$. As summarized in Table 6, the immune system is globally impaired in the elderly, which helps to explain the high incidence of infections and malignancies in this population $^{\mid[0]}$.
O envelhecimento é acompanhado de alterações na bemostase, observando-se um aumento de alguns factores de coagulação e resposta mais rapida das plaquetas a estímulos de agregação, o que, em conjunto aumento o risco de embolismo ${ }^{[4]}$.

Tal como se pode verificar pela tabela 6, o sistema imunitário do idoso está comprometido, o que justifica a elevada incidência de infeç̧ões e tumores malignos napopulação geriátrica ${ }^{[\theta]}$.

Tnble 6. - Main immunological changes occurring with aging $\left.{ }^{16-15}\right]$

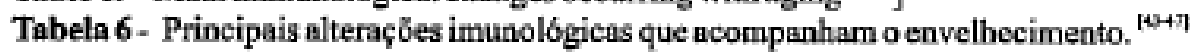

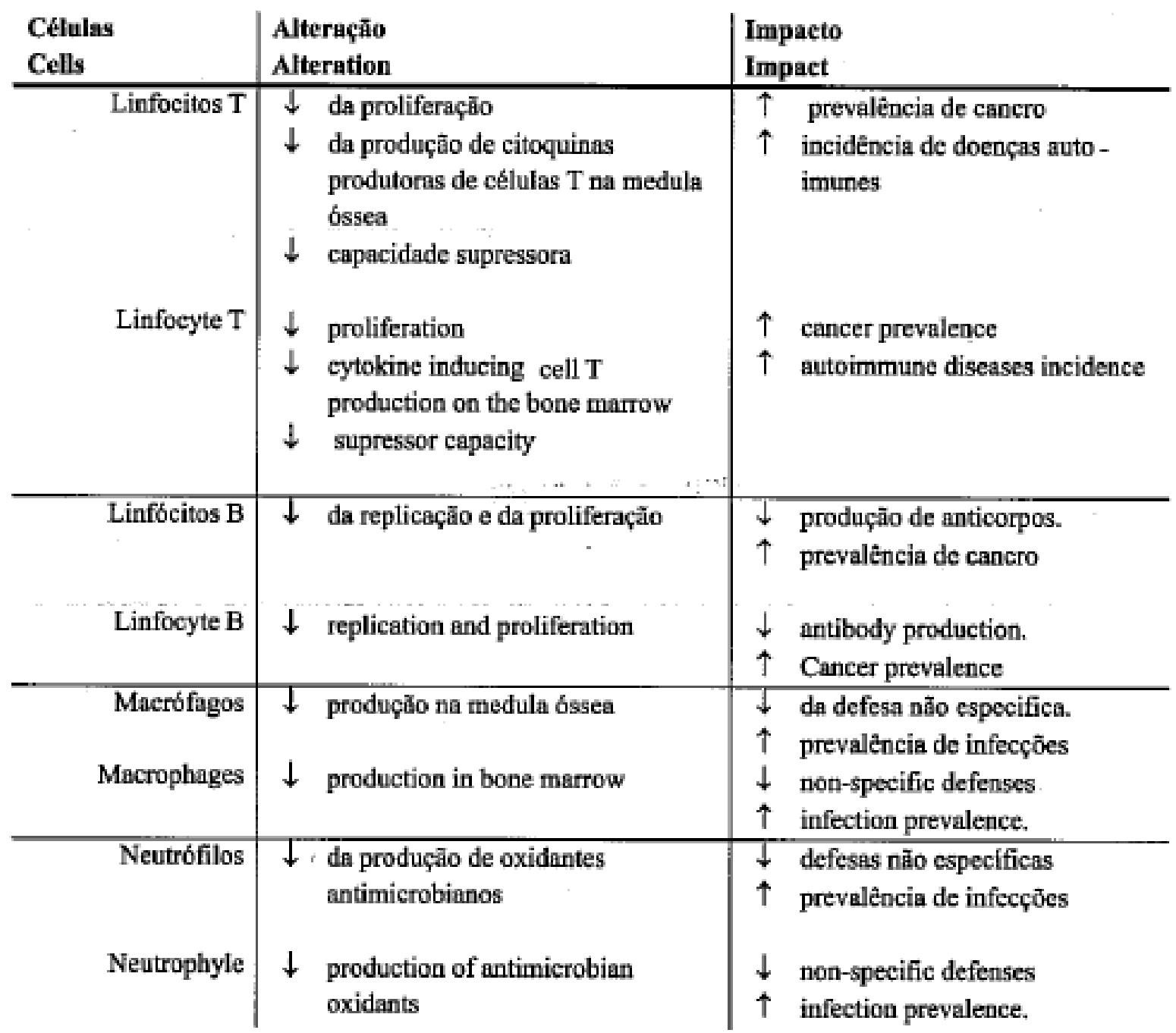

\section{Cardio-Vascular and Respiratory Changes}

The heart loses functionalities over the years, resulting from various structural changes ${ }^{[\$]}$. Cardiac remodeling involving hypertrophy or dilatation and some degree of fibrosis, determine the progressive loss of ventricular efficiency both in diastole and systole. The cardiac

\section{Alteraçōes Cardio-Vasculares e Respiratórias}

O coração perde funcionalidades com o passar dos

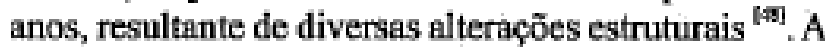
remodelação cardfaca, envolvendo a hipertrofia ou a dilatação e algum grau de fibrose, determinam a perda progressiva da eficiéncia ventricular na diastole e na 
rhythm reduction leads to changes in cardiac cycle timings while valvular calcification increases the strokerisk ${ }^{[4, \text {, ew }}$

For all these reasons, heart function decline seriously limits the life quality of geriatric population, being a major cause of morbidity and mortality in individuals over 65 years ${ }^{[6]]}$. (Table 7 )

The structural and functional changes in vessels; from large arteries where atheroma determinants are accumulated, to microcirculation where vasodilator response is decreased and vasoconstriction response augmented, arealsocharacteristicinoldpeople. Thebaro andchemical responsesarealsomodified(table 7) ${ }^{[4 k \text { en] }}$.

Regarding respiratory function, several changes occur. Reduction of elastin and collagen disorganization explains the progressive elasticity loss with is aggravated by muscle atrophy and parenchyma calcifications. The cough reflex and mucociliar transport are also depressed ${ }^{[3]]}$ (Table 7). Under these conditions, adaptation to stressful situations that require more oxygen delivery is suddenly difficult, compromising the integrity of other systems. ${ }^{\mid ⿰ 3 习\}}$. sistole. A diminuição do ritmo altera o tempo dos ciclos cardicos, e a deposiçũo de cálcio, em especial no sistema valvular, aumenta o risco de acidente cardiovascular ${ }^{\mathrm{r4}} 4.9 \mathrm{l}$. Por todas estas razões a diminuição da função cardiaca limita muito a qualidade de vida da populaçăo geriátrica, sendo uma das principais causas de morbilidade e mortalidade em indivíduos com mais de 65 anos (tabela 7) [49]

As alteraçōes, éstruturais e funcionais dos vasos, das artérias de grande calibre onde se acumulam os determinantes do ateroma, aos vasos da microcirculação onde diminui a resposta vasodilatadora e aumenta a capacidade de resposta vasoconstritora são caracteristicas. A resposta baro e quimireceptora fica também alterada (tabela 7) ${ }^{[4,63]}$

No que respeita à funçẵo respiratória, são várias as alterações registadas. Desde logo a diminuiçăo de elastina e desorganizaçâa do colagénio explicam a progressiva perda de elasticidade, agravada pela atrofia dos músculos do parênquima pulmonar e pelas calcificações. $O$ transporte mucociliar e o reflexo da tosse tambérn diminuem ${ }^{[3]}$ (tabela 7). Nestas condições, a adaptação a situaçōes de stress que exigem o aumento do aporte de oxigénio, é muito dificultade, compromentendo a integridade dos restantes sistemas ${ }^{[0]}$

Table 7 - Main age-related functional changes on cardio-vascular and respiratory systems (PVR - peripheral vascular resistance) ${ }^{t}$

Tabela 7 -. Principais manifestaçōes funcionais do envelhecimento nas funçð̋es cardio-vascular e respiratória (RVP

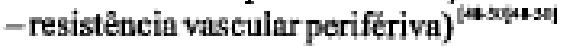

\begin{tabular}{|c|c|c|}
\hline Cardiace & Pascrilar & Respinatory \\
\hline $\begin{array}{l}\text { Reduction of the Ejection } \\
\text { Fraction and ventricular } \\
\text { volume } \\
\text { - increasing PVR and } \\
\text { - Hypertension } \\
\text { Diastolic failure and heart } \\
\text { - Aailure } \\
\text { - Arrhythmia } \\
\text { Atria-ventricular blockage }\end{array}$ & $\begin{array}{l}\text { - Atherosclerosis } \\
\text { - Peripheral Vascular } \\
\text { Disease } \\
\text { - Venous Failure } \\
\text { - Arterial pressure peaks } \\
\text { and pastural hipotension }\end{array}$ & $\begin{array}{l}\text { - Lung volumes and rigidity } \\
\text { increase } \\
\text { - Respiratory pressure } \\
\text { decreases } \\
\text { - Reduced expansion of } \\
\text { thoracic dage and air } \\
\text { netention within hungs } \\
\text { - Higher susceptibility for } \\
\text { diffusion infection }\end{array}$ \\
\hline
\end{tabular}

\begin{tabular}{|c|c|c|}
\hline Cardiacas & Fisculares & Rospiratorlas \\
\hline 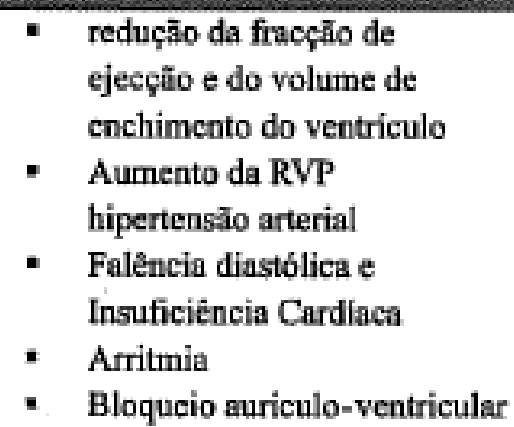 & $\begin{array}{l}\text { - Aterosclerose } \\
\text { - Doença Vascular } \\
\text { Periférica } \\
\text { - Insuficiéncia Venosa } \\
\text { - Picos de pressão arterial e } \\
\text { Hipotensđ̃o postural }\end{array}$ & $\begin{array}{l}\text { volume e rigidez pulmonar } \\
\text { aumentam } \\
\text { - Diminuiçı̃o da pressão } \\
\text { respiratória } \\
\text { - Limitaçăo na expensuão da } \\
\text { caixa torácica e retenção de } \\
\text { ar nos pulmões } \\
\text { - Maior susceptibilidade para } \\
\text { infeç̧ões de difusåo }\end{array}$ \\
\hline
\end{tabular}




\section{Gastro-Intestinal Changes}

Growing old also means a higher prevalence of gastrointestinal complaints ${ }^{[5]}$. The morphological and physiological changes that occur in the gastrointestinal tract of the geriatric population are varied, from the " mouth dryness " to gastro-esophageal reflux and constipation. The main changes are summarized in Table 8.

\section{Alterações Gastro-Intestinais}

Com o aumento da idade verifica-se uma maior prevalência de queixas gastrointestinais ${ }^{[34]}$. As alteraçōes morfológicas e fisiológicas que ocorrem no tracto gastrointestinal da população geriátrica são muito variadas, estendendo-se da "boca seca" ao refluxo gastro-esofágico e à obstipaçăo, As principais alterações desta natureza que ocorrem em função do envelhecimento estũo reunidas na tabela 8.

Table 8 - Main gastro-intestinal complaints and alterations related with ageing ${ }^{\text {Base }}$

Tabela 8-, Queixas mais frequentes e alteraçöes gastro-intestinais no idoso ${ }^{\mid \text {(a) }}$

\begin{tabular}{|c|c|}
\hline $\begin{array}{l}\text { Mechanism } \\
\text { Mecanismo }\end{array}$ & $\begin{array}{l}\text { Signs and Symptoms } \\
\text { Sinais e Sintomas }\end{array}$ \\
\hline Reduction of saliva secretion & Dry mouth \\
\hline Reduģio da secreçio de saliva & Boca secn \\
\hline Reduction of sensorial neurons & Madification in taste and smell perceptions \\
\hline Diminuiçăo de neturónios sensoriais & Alteraçōes da percepçૈే̂o do sabor e do olfacto \\
\hline $\begin{array}{l}\text { Superior Esophagic Esfincter resistance increases } \\
\text { and its relaxatlon is delajed } \\
\text { Aumento da resistência do esfincter esofagico } \\
\text { superior e atraso no seu relaxamento }\end{array}$ & $\begin{array}{l}\text { Refluxo gastro-esofágico } \\
\text { Gastro-esophagic neflux }\end{array}$ \\
\hline $\begin{array}{l}\text { Reduction of peristalsis and enteric nerves } \rightarrow \text { meuro- } \\
\text { degeneration }\end{array}$ & $\begin{array}{l}\text { Deglufing difficulties } \\
\end{array}$ \\
\hline $\begin{array}{l}\text { Diminuiģâo do peristaltismo e da inervação eatérica } \\
\rightarrow \text { neuro-degeneraçủo }\end{array}$ & Dificuldades an deglutiçăo \\
\hline Reduced intestinal absortion & Nutritional deficits \\
\hline Reduçâo da absorçalo intestinal & Défices nutricionais \\
\hline
\end{tabular}

Prolongamento do transito intestinal

Diminuiçăo da motilidade

Dieta pobre em fibras, consumo de ígua rechuzido,

Obstipation

diminuiçăo da actividade fisica e terapêutica

furmacológica multipla

Intestinal transit is prolonged and motility neduced

Low-fiber diet, reduced water consumption, weak

physical activity, and multiple pharmacological

Obstipação

therapeutics

Reduced hepatic and pancreatic functions

Decreased productian of digertive juices

Reduçio da funçào hepatica e pancré́tica

Reduçio da produçĩo de sucos digestivos

\section{Genital-Urinary Changes}

The kidney is one of the most affected organs with ageing, duc to fibrosis that progressively affects the nephron. For this reason, urine is not highly

\section{Alteraçōes Genito-Urinárias}

O rim é um dos órgãos que mais se altera com o envelhecimento em função da fibrose que, 
concentrated while the filtration and elimination abilities are frankly diminished over the years ${ }^{51 !}$.

Changes in fluid and electrolyte composition that usually occur are also due to decreased production of renin and $\mathrm{u}$ efficiency reduction of aldosterone activity in the distal tubule ${ }^{\text {16: }}$ (table9)

Male and female reproductive systems undergoes marked changes specially based on the progressive loss of neurohumoral regulation. In men, these changes inyolves ${ }^{\mid m, n}$,

- Prostate swelling, by increasing the rate of cell proliferation

- Decreased libido resulting from the reduction of androgens, reduction of erectile capacity, associated with vascular disease, autonomic nervous system disorders and use of other drugs (co-morbilities)

- Delay in erection, decreased intensity of orgasm, decreased ejaculation volume.

In women, changes in the reproductive system begin in an earlier stage of life (menopause), involving ${ }^{\text {(n)! }}$

- Hair thinning and whitening

- Vaginal dryness, which predisposes the development of erythema and vaginal atrophy and changes of uterus and cervix position as well,

-increase of vaginal $\mathrm{pH}$ and blood flow reduction

- loss of follicular cells, granulosa and theca (ovaries) progressivamente, afecta o nefron. Por essa razão, a urina do idoso é pouco concentrada e a capacidade de filtraçäo e eliminaçüo ficam francamente diminuidas com o passar dos anos ${ }^{[\hat{n}]}$. As alterações dn composição hidroelectroliticas que surgem sāo também devidas à diminuiçũo da produçẩo de renina bem como à diminuiçîo da eficiência da aldosterona sobre o tubulo distal ${ }^{(0)}$ (tnbela 9) .

$\mathbf{O}$ aparetho reprodutor, quer masculino quer feminino, sofre acentuadas altérações em função da perda progressiva de regulaçǘo neuro-humoral. No homem, este alteração envolve ${ }^{\mathrm{MA}, \mathrm{m})}$ :

-Dilataçâo da próstata, por aumento da velocidade de proliferaçäo celular

- Diminuição da libido resultante da reduçäo dos androgénios e redução da capacidade eréctil, associada a doença vascular, alteraçôes do sistema nervoso autónomo e utilização de outros medicamentos (co-morbilidades)

- Atraso na erecçăo, diminuiçào da intensidade do orgasmo, reduçåo do volume de ejaculação

Na mulher, as alteraçōes do sistema reprodutor têm inicio numa fase muito mais precoce da vida (menopausa), envolvendo ${ }^{\text {(5t)! }}$

- Diminuiçāo da espessura e embraquecimento do pelo

- Secura vaginal, o que predispõe o desenvolvimento de eritemas $\mathrm{e}$ atrofia vaginal e alteração da posiçẫo do útcro $\mathrm{e}$ do cérvix;

- Aumento do pH vaginal e reduçâo do fluxo sanguineo

- Nos ovários verifica-se perda de células foliculares, granulosas e da teca

Table 9 - Main urinary changes in the elderly (GFR - Glomerular Filtration Rate) ${ }^{\text {(is-a) }}$

Tabela 9 - .Principais alterações da função urinária no idoso (GFR-Intensidade de filtração glomerular)

\begin{tabular}{|c|c|}
\hline Mrechanisut. & Sygurs and Sympronis. \\
\hline $\begin{array}{r}\text { Glomeruli degeneration with nefron loss and renal } \\
\text { fibrosis } \rightarrow \text { permcability increases }\end{array}$ & $\begin{array}{ll}\uparrow \quad \begin{array}{l}\text { arteriolar afferent and efferent atrophy . dircet } \\
\text { channels between arteriolcs are formed }\end{array} \\
\text { (compensatory mechanism) } \\
\downarrow \quad \text { surface area and GFR } \\
\uparrow \quad \text { protein in the urine }\end{array}$ \\
\hline $\begin{array}{r}\text { Reducton of tubular function in the thick ascending } \\
\text { linb of Henle's loop and reduction of aldosterone and } \\
\text { renin secretion }\end{array}$ & $\begin{array}{ll}\downarrow & \text { reabsortion of salt and water, and potassium } \\
\text { secretion }\end{array}$ \\
\hline $\begin{array}{r}\text { Reduction of the bladder contractility and esficter } \\
\text { control in the uretra } \\
\text { Hiperactivity of the detrusor muscle }\end{array}$ & Urinary incontinence \\
\hline Mfecrinismo & Sinais e Sintromis \\
\hline $\begin{array}{l}\text { Degeneraçāo do gloméralo com perda de nefíónios e } \\
\text { fibrose renal } \rightarrow \text { aumento da permeabilidade }\end{array}$ & $\begin{array}{ll}\uparrow & \text { Atrofia arteriolar aferente e efereate. Formaçio } \\
& \text { de canais directos entre as arteriolas (mecanismo } \\
& \text { compensatório) } \\
\downarrow & \text { da área de aperficie c da GFR } \\
\uparrow & \text { Proteinas na urina } \\
\end{array}$ \\
\hline $\begin{array}{r}\text { Reduçăo da funçũo tubular na zona ascendente da } \\
\text { ansa de Heale e diminuiçîo da produção de } \\
\text { aldosterona e de renina }\end{array}$ & $\begin{array}{l}\downarrow \quad \text { da reabsorção de sal e água, e da secreçīo de } \\
\text { potússio }\end{array}$ \\
\hline $\begin{array}{r}\text { Redugio da contractilidade da bexiga e de controle } \\
\text { dos esfinteres da uretra } \\
\text { Hiperactividade do músculo detrusor }\end{array}$ & Incontinência Urinária \\
\hline
\end{tabular}


Special Pharmacological and Pharmacotherapeutics features of Ageing pharmacokinetical changes in the elderly.

Ageing determines, for most individuals, changes in physiological responses to drugs, affecting the pharmacokinetic parameters (Table 9$)^{[m]}$.

The risk of drug toxicity in the elderly is increased, meaning that it is necessary to adqeuate dosis and monitor the action of drugs, specially in certain cases $^{172}$ 73! Benzodiazepines and hypnotics half-life is increased from 50 to $150 \%$ between 30 and 70 years of age. The decline of renal and liver function contributes to reduce the elimination rate of these compounds and there is also an increase in its distribution volume ${ }^{59 /}$

Hypertension therapeutics are quite common in the elderly. However, the occurring pharmacokinetic and pharmacodynamic changes recommend special care in choosing the right medicines. Thiazide drugs must alert tó hypokaliemia, hyperglycemia and hyperunimenia, since elderly frequently suffer from arrhytmia, type II diabetes and gout. ${ }^{\text {(10si }}$ Beta-blockers are potentially dangerous in patients with respiratory disease. These patients taking anti-hypertensive medication should be strictly controlled to avoid orthostatic bypotension [103]. Digoxin is frequently used for heart failure. However, its clearance is decreased in geriatric patients and its half-life may be increased up to $50 \%$. Hypokaliemia, hypomagnesaemia, hypoxia and atherosclerosis lead to an increased incidence of arrhythmias in old patients treated with digitalis. Other toxic effects, including delusion, visual impairment and endocrine abnormalities may also occur ${ }^{\text {[not }}$

Pain is frequently treated with non-steroids antiinflammatory drugs (NSAID). However these tend to originate toxic effects, such as peptic ulcer, fluid retention, kidncy damage and heart failure. Renal impaiment reduces drugs clearance, which remains in the body for longer in periods, aggravating the nephropathy. Anti-inflammatory steroids are an excellent alternative when NSAID are contraindicated. Howeyer these promote osteoporosis, a well known complicant pathology in ageing ${ }^{1059}$.

\section{Particularidades Farmacológicas e Farmacoterapêuticas do Envelhecimento - alterações farmacocinéticas no idoso.}

O envelhecimento determina, para a maioria dos individuos, alterações nas respostas fisiológicas aos färmacos, afectando necessáriamente os paråmetros farmacocinéticos (tabela 10) ${ }^{\mathrm{II}}$ ?

O risco de toxicidade medicamentosa no idoso está aumentado, o que significa ser necessírio a um ajuste da dose e à monitorização da acção dos fărmacos, especialmente em alguns casos ${ }^{17,7}$, 7 . O tempo de semi-vida das benzodiazepinas e hipnóticos aumenta de 50 a $150 \%$ entre os 30 e os 70 anos de idade. $O$ declínio da função renal e hepática contribuem para a redução da velocidade de eliminação destes compostos. Verifica-se também um aumento do seu volume de distribuição. ${ }^{[m]}$.

O tratamento da hipertensão no idoso é bastante corrente. No entanto, devido às alteraçôes farmacocinéticas e farmacodinåmicas anteriormente mencionadas, deve sempre ser prestado especial cuidado na escolha e prescrição dos medicamentos. $\mathrm{Na}$ escolha de fármacos tiazidicos, devemos estar alerta para o risco de hipocaliemia, hiperglicémia e hiperurinemia associadas a este grupo terapêutico, visto que o individuo idoso sofre frequentemente de arritmia, diabetes tipo II e gota. Os bloqueadores-beta são potencialmente perigosos em doentes com patologia respiratória. $O$ doente idoso sujeito a medicaçåo anti-hipertensiva deve ser controlado rigorosamente de modo a evitar a hipotensão ortostática. ${ }^{[100]}$ A digoxina é um färmaco utilizado no tratamento da insuficiência cardiaca. No entanto a sua depuração diminui nos grupos etários mais avançados e o seu tempo de semi-vida pode aumentar até $50 \%$ do seu valor normal. A hipocaliemia, a hipomagnesémia, a hipoxia e a aterosclerose levam ao aumento da incidência de arritmias em idosos medicados com digitálicos. Podem também surgir outros efeitos tóxicos, nomeadamente delírio, alteraçōes visuais e anormalidades endócrinas. ${ }^{\text {}}{ }^{\mathrm{or}}$

Relativamente ao tratamento da dor, é necessário recorrer-se frequentemente a anti-inflamatórios não esteroides. No entanto estes tendem a desencadear efeitos tóxicos no idosos, incluindo a úlcera peptídica, a retenção de líquidos, e a lesão renal e cardíaca. A lesão renal leva a uma menor depuração destes fármacos, que ao permanecerem por mais tempo no organismo agravam a nefropatia. Os corticosteróides são uma boa alternativa em doentes onde o uso de AINE's está contra-indicado. Contudo, estes fármacos promovem a osteoporose, uma patologia complicante típica do envelhecimento ${ }^{[105]}$ 
Table 10 - Main pharmacokinetic changes occurring with ageing ${ }^{[\mathrm{m} \cdot \mathrm{rm})}$

Tabela 10 - Principais alteraçöes farmecocinéticas que ocorrem no envelhecimento. [r.7!]

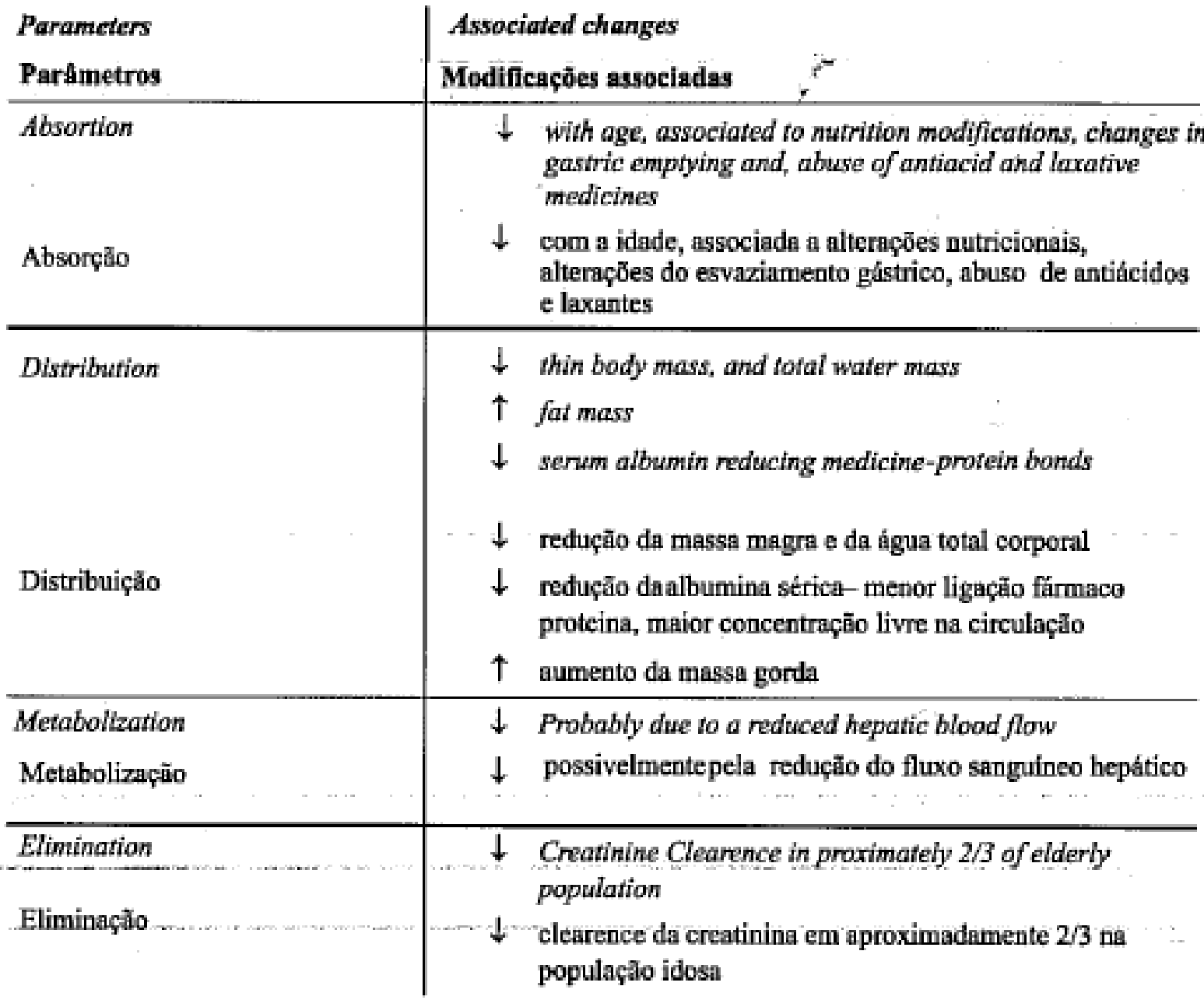

\section{Conclusions}

Ageing affects all biological systems increasingly committing their function. However, the progressive knowledge on this particular pathophysiological process is contributing in an obvious manner to reduce the evolution of this process, though inexorably, increasing life expectancy and their quality. Thus, the pathophysiology of ageing is a key theme of prevention of disease associated with the process, but also health promotion, including promotion of effective therapy.

\section{Conclusăo}

O envelhecimento afecta todos os sistemas biológicos compromentendo progressivamente a sua função. Contudo, o conhecimento já acumulado sobre este processo fisiopatológico especial vem contribuindo para reduzir de forma evidente o seu progresso, apesar de inexoravel, aumentando a esperança de viđa bem como a sua qualidade. Desta forma , a fisiopatologia do envelhecimento é um tema essencial da prevenção da doença associada ao processo, mas também da promoção da saúde, incluindo a promoção da efectividade terapêutica. 


\section{References / Referêncins}

II] Caruso Lisa B, Silliman Rebecea A.: Fatrisod Principles of Internal Medicine, 2008 ITed, perte 1 . cos 9:53-62.

[2] Stadtren Eert: Modem Theories of Aging: Natienal Institutes of Health, 2002

[3] Weitrent T Brian, Timirus Poala S. Phyaialogy of Aging lavited Reviear: Theories of aging. Jowneal of Applied Fiysiology 2003, 95:1706-1716,

[4] Kinsella, Kevin; He Whan. An Aging World: 2006. US Consus Burvan, Intemational Datubase, 2008 [5] WHO's Ageing and Life Course Programme. ActiveA Aing. A policy Framework 2002. (1):6-11

(6) Zglinicki T, Saretzki G, Docke W. Mild byperoxin shortens telomeres and inhibit prollferation of fibcublasts: a model for senescence? Experimentat Cell Resencth, 1995, 220:186-193,

[7] Finkel, Toren, Holbrook, Nikki I, Oxidants, owidative stress and the biology of ageing, Nature 2000, 208: 239-247

[8] Gryton, Hall Functional organization of the hunaan body and control of "Internal Envirumetet" Textbook of medial physiology $11^{\prime}$ ed 2005 . 1: 3-10 [9] Bunks A, Morley E. Endocrite end metrbolis ctanger in humrar aging Ape. 2000, 23 (2):103-115. [10] Bisbog Nicholas, Lu Teo, Yankne Bruce. Review Article: Neural mechanisms of ageing and cognilive dectine Nature 2010,464:529-535

(1i) Matson Mark P, Chas Sic L Doae Wenten. Motilieation of BtrinA Aing and Narrodegenerative Disorders by Genes, Diet, and Behevior. Phyriological Reviews 2002, 82; 637-672.

[12] Holf Parrick R, Bossitce Thierny, Bunbusm Jeseph D, Morrisen John. Newtobiologic Busis of Age-releted Demeating Disorders, Geriatric Medicine: an evilenter bused approsch $4 \% \mathrm{ed}, 2003$, 75:t095-11

[i3] Bree GA, Andrews GR, Caird F, Gilmere AJ, Mclemenan WJ. Neuralogical disonders in the eldetty at boex. Joumnl of Neuronurgical Psychinery, 1976, 39:362-366.

- [I4]:Miraker KI. Consmon clinical sequelese of aginz Cocil Mecticine23"od. 2007, 23:225-234

[15] Knight, J. Nigam, Y. Explaring the anativany and piryslology of ageing part 7 The Eindocrine Syctem. Nurring Times $2008104:(45) 24-25$.

[16] Hotta Harumi, Uehide Sac. Asing of the uutonoticic servous 5 ytem and possiblo ifmprovenents in autanonis activity using somstie afferent stimulation. Geriatrics and Geromblogy Interview 2010. 10(1)-S127-8136

[17] Mazzeo RS, Rajkumar C, Jennings G, Ealer M. Norepinephrine spillover ot rtat and during submaximal exercise in yeang and old rubjects. Joumal of A pplied Ptyziolosy 1997;82:1869-1874 [18] Flood C, Gberoutache C, Pincua C, Tait S G, Willoughby $J$. The Metabolism nnd Secretion of Aldoaterone in Elderly Subjects. Clinical Invatigation 1967, 46(6): 960-966

[19] Samos LF, Roos BA. Disbetes weil lites is older persons. The Medical Clinics of North Ametica 1998; $82: 791-803$

[20] Meneilly GS, Deraan K. Tessice D. Aiterations in glatese metabolism in the elderiy patient with diebstes. Disbetes Care 1993; 16:1241-1247

[21] Shermen BM, West JH, Kurcaman SG. The menopensal transition: arulysis of LH, FSH, estindiol, and proptsitruce coocentrations during metsitrual cyeles of older women. Journal of Clinical Endocrinelogy and Metabolism 1976; 42:629-636.

[22] Snowten DA, Greiner LH, Mortimes JA, Riley KP, Greiner PA, Markesbery WR. Brain infaretion and the clinieal expression of Alateinet diseses. The Nun Sucty. JAMA 1997;277:513-817

[23] Godschnlk MF, Siron A, Mulligan T, Management of ertetile dysfunction by the geriatarician, Journal of Anerictan Geristrio Society 1997;45: 1240-1246.

[24] Morley JE, Kniser FE, Perty HM III, Patrick P, Motley PMK, Stauber PM. Longiturfinal changes in testnsterone, luteinizing bormoae, and follicle- stimulating hormese in healthy older men. Metebolisen 1997; 46:410-413.

[25] Robert Sissen B, Rasenherg irwin. Nutrition and Aging: Changes in the Regulation of Energy Metsbolism With Aging. The American Physiological Society 2006, 95: 651-662.

[26] Wilson Margeret-Mary, Mariey John. Physiology of Aging lavited Review: Aging and energy balence. Joarnal of Applied Fysiology 2003 95: 172B-1736

[27] Kenney Lamy, Munce Thayne Physiology of Agiag Invited Review: Aging and human temperatare regulation. Journal of Applied Plyyiotory, 2003, 95: 2598-2603

[28] Frotanim, Amy Krupricks Gortorn, Marshe Dermatologit Disenses and Probletrs. Gerintric Molicine: An evidence based approsch 4" od 2003. 58: 869-882

[29] Bologmina, Jean L. Aging skin. The American Journal of Modicine, 1995, 98\% (1) S99-S103

[30] Quimga, Refuels M. Anti- $\Lambda$ ging Medicine as it relates to Dermsialegy. Cosmetic Derratelogy 2005, 1(1):16.

[31] Zaulyanov-Scanlan, Larisan. Hermoaes and Aging Skin Cosmetic Dermacology: Prixiples and Practise of" od, 2009, 5:29-33.

[32] Froemen, Any Krupaick Gerton, Marshe. Dermatologic Disenses and Problems. Gerintric Medicine: Al evidence based approach $4^{2}$ ed, 2003 . 5B: $869-882$

[33] Inxerillo, Angela; Iqbal, Janeel; Treen, Bruce. Sketal Frogility in the Elderly. Geriatrie Medicine: An evideoco based approach. $4^{0}$ of $2003,43: 621$ 650

34] Srivastava, Manish; Deal, Casd Osteoporosis in elderly: prevention nad treatunete. Clinica in Geriatric Medicine 2002, 18:529-555

[35] Natienal Osteoporosis Foundation, Osteoperusis: review of the evidence for prevention, diagnosis, and trestment and cost-effective analysis. Osterporosis Int Suppl. 1998; S7-S80

[30] Verniag. Geoff. Recent developenests it vitamin D deficicncy and mascle weakness amodr elderly people. -British Medieal Journal 2005; $330 \cdot 352$

[37] Daniel; Sarensen Leif, Ellman Michael. Pheanstologic Diseases. Geriatric Medicine: An Eviddense based spprosech, 4'ad, 2003, 42.573-620, [38] Belngorul P, Roopackens OE, Adey DB, Ades PA, Nair KS. Efects af aging on in vivo synthesis of skeletal ausele myosin beavy-chsin snd sarcoplasmic ptetein in humans. American Journal of Prysioloky. 1997, 273-E790-800.

[39] Neir, Steckumarna K. Aging Musele. America foumsl of Clinical Nutritioe, 2005, 81 (5): 953-963) [40] Carmed R, Green R, Roseniblen D, Lpelste on subalamin, falace and herrocysteine. Hamatologer 2003:6?-81

(41] Cella D, Bron D. The efftet of epoictin elfa o quality oflife in macanic cancer patienta. Caves Proction. 1990:7: 1777182

[42] Abbate Rosanns, Priseo Demenico, Rastugno Cselo, Boddi Meris. Age-retated changes in the hemustatic system. Interrationel Joumel of Clinical \& Labaratory Revearch 2000, 30(4):179-185 [43] Miller $\mathrm{B} /$. Aging atd immune finction. leterational Roview of Cy tology. 1991: 124:187-215

[44] Ooodwin JS, Searles RP, Tung KSK. Immunolagieal tespontes of a bealthy elderly population. Clinjoal and Experimented Immusobogy $1982 ; 48: 407-410$

[45] Milier RA. Aging and hremec fusetion: collula and bischemical ktalyses. Experimentzl Gercutobgy. 1994: 29:21-35

46] Hoyer, MG, Ment C, Wa D. Enherced appression of indueitle crclooxygenase with age io murine macrophnges Jamnei of loutumsloge. 1997; 159:2445. 2451

[57] Bums, Edith A; Goodwin Jkmes S. Immunalogy of Aging. Gerietric Medictine: An evidence basat nppouch tod 2001, 53:783.802.

[43] Wenger Nanette Kass. Cerdisvascular Discase Geriatric Meticins: An ovidesce hroed apposech. 4" od $2000,39.509-544$.

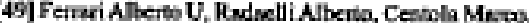

Physiology af Aging Invitad Review; Agirg and the

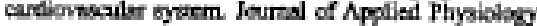
2003, 95: 2591-2597.

[50] Ferrari Albetio U. Medificatians of the Cardiovascular Sysiem With Aging The American Jaunal of Geristric Cartiology. 2002, 11(1): 30-34

[51] Wetster Ir, James 2. Pulmonary Distase. Geriatric Medicine: An eviderike besed approsch Aed, 2033, 57 : $853-860$.

[52] Shanval Golsham, Coodurin James. Effeet of aging on restintery sysiem physiolosy and immunolog: Clinical letarention on A ging $2006 S$; 1 (3): 253-260.

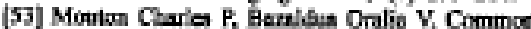
Infections in OSler Adalis American Ptysicien, 2001, 15:63(7): $257-269$

[54] Sallea, N. Batic Mecherisma of the Agiag Gessoinatestinal Tract. Digestivo Disorlhes 2007; 25:112-117

[55] Pot Choo Hesn, Navarro-Rodrigues Tomis, Fass Rennie. Treatment of Gastroesophageal Refux Disesse In the Eilaty. The Annerican Joumed of Medicine 2010, 123:496-50i

[56] Madkm JL, Graff J. Effects of toing on gastrointertind motor function. $A_{50}$ and A ging 2004; 33: 154-159

[57] Phillipa RJ, Kieffe EJ, Poultry $\pi \cdot$. Aging of the

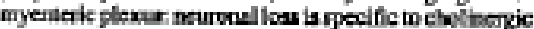

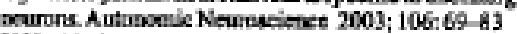
[58] Mrisen II. Graff J: Effects of aging on gastrointestinal motar foretion Agro and Agiog 2004; 33: 154-159

[59] Gomes OA, de Screa RR, Liberti EA, A prelirninury aveatigation of the effects of aging on the neve coll number in the myenteric genglin of the burmen colen. Gerceltoblegy 1997; 43:210-217

[G0] Spinzi GC. Bowel Care ba the Flterly. Digerive Diverdeas 2007:25:160-165

[61] Andersan Sheran. Nepbrology/Fluid and Elecsotyte Disonden. Geriatrio Medicies: An evidenta based approsch 4"ed, 2003, 52: 769-782.

[62] Greenleld Ziv, Boglis Chris. Aging and the rens cirruhation Adranes in Organ Biologia. 2000, 9.255.

[63] Anderean Starun, Bkrty MD, Bemner M. Efiects of

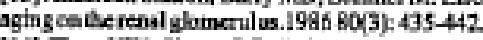
[64] Tietz NW, Stuvey DF, Wekgtein DR. Leberatary values in fit eging individuals-scregenarians derpoj ctnterariane Clinical Cheanisty, 1992,38, 1]67.1185.

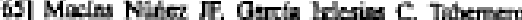

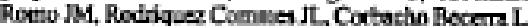
Sancher Tomero JA. Renal meregement of sodlum uncler indemethasin and eldouterune in the olderly. Age nad Ageing 1980,9:165-72

66] MeAloon Dyke M, Davis KM, Clevk HA, Fish LC,

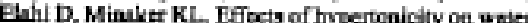

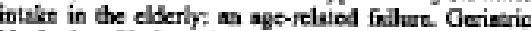
Neptralogy Umology, 1997; 7(1:11-6

[67] Footl IA Newras DK, Colling L. Urinery ncontinemee in Adulte: Acute ond Chranie Managenent. Clinical Practice Guidetios, 1996, 2: 153. 168

[68] Francoì Mornique, Moulln Theresc, Hamas Johin Peter. Urinery ineonfinence in older stulta recelvives

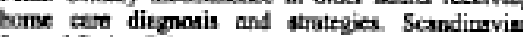
Journal Csing Sciente. 2009; 23:222-230

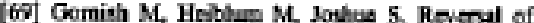
benign prostale byperplasia try seloctivs ocehalios of iepeirod venous drains ge in the male reprobuetive vystem: novel mechroism, new treatment Andrologis $2035,40-273-281$

[Je] Malligan Thoous, Sikki wi Walred. Changes in muls serustity, Otrietric Medicine; An evidentre besed sproact 4ted 2013, 48: 719-726

[fi] Tirmens Cryotio M. Oynecolagie asd Urologie Problems of Older Whemen. Gerituric Medisize: $\lambda$ eridenee butad sppouch 4'ed, 2003, 50:737-753

[7] Katrong Bertram G. Aspoctos Especisis do Ferbacelogia Geribtrica. Fermacologin Bísica Clinita, 9\%od, 2005, 61: $844-850$.

[73] Hutshison Liss C. Changes in Phermeskincties and Phstmscodynernics in the elderly. Jeumel af Phamacy Practice 2007, 20:4-12.

74] Cova Dtrio, Lerusce Vits, Siluestris Nicola. The Pharracoldinetica atd Phormacodynumics of Drugs in Eldetly Cachtectic (Cenacer) Patients Cachexis end Watiogs A modern approwech. 2066, 7:337-3K2 [75] Alagiekrishon K. Wien C. An nowoecl so dru inducod delirium in the elleriy. Pestanted Medico Joumed 2904, 8049-15) 388-393 